\title{
The effect of Silymarin on VEGF, VEGFR-1 and IL-1 $\alpha$ levels in placental cultures of severe preeclamptic women
}

\author{
Mustafa Derda Kaya ${ }^{1}$, Eralp Başer ${ }^{1}$, Sibel Kaya ${ }^{1}$, Mustafa Kemal Takal ${ }^{1}$, Feride Şahin ${ }^{2}$, Esra Kuş̧̧ ${ }^{1}$, Filiz Yanık ${ }^{1}$ \\ 'Department of Obstetrics and Gynecology, Baskent University Faculty of Medicine, Ankara, Turkey \\ ${ }^{2}$ Department of Medical Genetics, Başkent University Faculty of Medicine, Ankara, Turkey
}

\section{Abstract}

Objective: The purpose of this study was to evaluate the effects of Silymarin on vascular endothelial growth factor (VEGF), soluble VEGF Receptor-1 (sVEGFR-1) and Interleukin-1 alpha (IL-1 $\alpha$ ) levels in placental tissue samples of severely preeclamptic women.

Material and Methods: We conducted an in vitro study in Başkent University Faculty of Medicine, Ankara, Turkey between September 2008 and May 2009. A total of 16 placental tissue samples ( 8 from severe preeclamptic, and 8 from controls) were analysed. Placental samples were incubated, and VEGF, sVEGFR-1, and IL1- $\alpha$ were measured in culture media using an ELISA kit. The effect of Silymarin on these levels was investigated. Descriptive statistics were initially performed, followed by Mann Whitney U-test and Kruskal-Wallis test to compare means between groups. P values less than 0.05 were considered statistically significant.

Results: Eight patients were included in the severe preeclampsia (SP) group, whereas the remaining 8 patients were included in the control group. There were no significant correlations between gestational age and placental VEGF, sVEGFR-1 and IL-1 $\alpha$ after 48 or 72 hours of incubation. Basal VEGF levels were lower in the SP group; however, it did not reach statistical significance. sVEGFR-1 and IL-1 $\alpha$ levels were also similar between the SP and control groups ( $p>0.05$ ). After 48 and 72 hours of incubation, sVEGFR-1 levels in Silymarin-added SP and control placental cultures were lower than in the samples without Silymarin addition; however, this difference also did not reach significance.

Conclusion: Although we could not demonstrate a significant effect on placental cytokines, considering the role of vasospasm, inflammation, angiogenesis, endothelial cell activation, and oxidative stress in preeclampsia, the potential benefits of Silymarin should be evaluated in future trials with a larger sample size. (J Turk Ger Gynecol Assoc 2014; 15: 30-5)

Key words: Severe preeclampsia, placenta, vascular endothelial growth factor, Silymarin

Received: 17 August, 2013

Accepted: 30 September, 2013

\section{Introduction}

Preeclampsia is a syndrome that is specific to pregnancy, and is mainly characterised by decreased organ perfusion secondary to vasospasm and endothelial activation. The pathophysiological changes observed in preeclampsia develop with the influence of genetic, immunological and inflammatory factors (1-3). In healthy pregnancies, spiral arterioles within the uteroplacental bed are invaded endovascularly by the trophoblasts; thus, they are converted to vessels with low resistance, low pressure and high blood flow (4). Vascular endothelial growth factor (VEGF) is thought to play an important role in placental evolution, particularly in angiogenesis and microvascular permeability (5). VEGF production was previously reported to be decreased in preeclampsia (6). VEGF acts by binding to the tyrosine kinase receptors VEGFR-1(Flt-1) and VEGFR-2 (7-12). However, free VEGFR-1 in the circulation (sVEGFR-1 - soluble VEGFR-1) has a strong antagonistic effect on VEGF and placental growth factor (PIGF). High sVEGFR-1 levels are detected in preeclamptic pregnant women compared with normal pregnant women, and these high levels are thought to have negative effects on angiogenesis (13). Studies on preeclamptic pregnancies have also shown that placental interleukin-1 (IL-1) has a key role in maternal inflammatory response and endothelial activation (14-16).

Silymarin is a flavonoid, which is extracted from the plant Silybum marianum. Its major bioactive component is Silybinin. It has anti-proliferative, pro-apoptotic, anti-angiogenic, antiinflammatory and anti-fibrotic effects (17-24). This study was designed to evaluate the effects of Silymarin on VEGF, VEGF Receptor-1 (VEGFR-1) and IL-1 alpha (IL-1 $\alpha$ ) levels in placental tissue samples of severely preeclamptic women.

\section{Material and Methods}

\section{Patient Selection}

We conducted an in vitro study in Başkent University Faculty of Medicine, Ankara, Turkey between September 2008 and 
May 2009, following scientific and ethical approval from Başkent University Institutional Review Board (BUTF IRB Approval No:08/59, 02.04.2008). A total of 16 placental tissue samples (8 preeclamptic, and 8 controls) were analysed.

After obtaining informed consent, severe preeclamptic women who underwent caesarean section above 30 weeks of gestation were prospectively included in the study. Severe preeclampsia (SP) was defined as new-onset hypertension and proteinuria in $\mathrm{a}>20$ week pregnant woman with one or more of the following features: 1) severely elevated blood pressure (systolic $\geq 160 \mathrm{mmHg}$ and/or diastolic $\geq 110 \mathrm{mmHg}$ ) measured at least twice with a 6 hour interval; 2) proteinuria $\geq 5$ gr in 24-hour collected urine or $\geq 2+$ in dipstick test; 3 ) serum creatinine $\geq 1.2$ $\mathrm{mg} / \mathrm{dL} ; 4$ ) oliguria ( $<400 \mathrm{cc}$ in 24 hours); 5) thrombocytopenia $\left.\left(<100,000 / \mathrm{mm}^{3}\right) ; 6\right)$ microangiopathic haemolysis (Lactate dehydrogenase $(\mathrm{LDH}) \geq 600 \mathrm{U} / \mathrm{L}$ or uncongugated bilirubin $\geq 1.2 \mathrm{mg} / \mathrm{dL}$ ); 7) impaired liver function tests (Aspartate serum transaminase $\geq$ twice normal); 8) foetal growth restriction (FGR); 9) symptoms of central nervous system dysfunction (severe headache, blurred vision); 10) symptoms of liver capsule distention (epigastric or right upper quadrant pain); and 11) symptoms suggesting pulmonary oedema (dyspnoea) or cyanosis.

Patients with pre-existing hypertension, diabetes, renal disease, and patients in whom steroids were used for foetal pulmonary maturation were excluded from the study. A control group comprising 8 women with a normal pregnancy follow-up, who underwent caesarean section $(\mathrm{C} / \mathrm{S})$ due to a previous $\mathrm{C} / \mathrm{S}$ and gave informed consent, was constituted for comparison with the SP group.

\section{Preparation of Placental Samples}

During caesarean section, a $1 \times 1 \mathrm{~cm}$ sample of placental tissue sample involving foetal membranes and decidua was obtained using a sterile technique. Placental samples were placed in a transport medium RPMI-1640 (PAA Cell Culture Company, NJ, USA) and was transferred to the laboratory in $+4^{\circ} \mathrm{C}$ containers within 12 hours of delivery. Samples were further separated into chorionic villi under laminar airflow. Culture medium was composed of $5 \%$ foetal bovine serum, 1\% Penicillin-Streptomycin, and $2 \%$ L-Glutamine (Biochrom KG, Berlin, Germany).

A total of six wells were processed for each placental sample. Each well contained $0.5 \mathrm{~mL}$ of culture medium and $20 \mathrm{mg}$ placental tissue. The 1 st and 4 th wells were processed without Silymarin. Silymarin concentrations in wells were based on the study by Wang et al. (25). Concentrations of $6.25 \mathrm{mg} / \mathrm{L}$ were achieved in the 2nd and 5th wells. In the 3rd and 6th wells, 25 $\mathrm{mg} / \mathrm{ml}$ Silymarin concentrations were achieved (Table 1).

Placental samples were incubated in $\mathrm{a} \mathrm{CO}_{2}$ incubator (Heraeus, Thermo Scientific Corp., Asheville, NC, USA) in a $5 \% \mathrm{CO}_{2}$ environment. Incubation durations were 48 hours for the 1 st, 2nd and 3rd wells, and 72 hours for the 4th, 5th and 6th wells. Upon completion of the incubation period, incubated cultures were transferred into sterile Eppendorf tubes $(1.5 \mathrm{ml})$ and were transferred at $+4^{\circ} \mathrm{C}$ to the laboratory for biochemical analysis.

\section{Measurement of Placental Cytokines}

Samples transferred for biochemical analysis were initially stored at $-80^{\circ} \mathrm{C}$ until reaching the kit sample size. Samples were then defrosted, and Vascular Endothelial Growth Factor (VEGF), soluble VEGF receptor-1 (sVEGFR-1) and Interleukin (IL)-1 $\alpha$ were measured in culture media using an ELISA kit (Bender MedSystems, Austria).

\section{Statistical Analysis}

Statistical analysis of the study data was performed with SPSS 16.0 (SPSS Inc., IL, USA) software. Descriptive statistics were initially performed, followed by Mann Whitney U-test and KruskalWallis test to compare means between the groups. Correlations between variables were assessed with Spearman's correlation analysis. $\mathrm{P}$ values less than 0.05 were considered statistically significant.

\section{Results}

A total of 16 patients were included in the study. Eight patients were included in the severe preeclampsia (SP) group, whereas

Table 1. Processing order of the placental samples

\begin{tabular}{|l|c|c|c|c|}
\hline $\begin{array}{l}\text { Well } \\
\text { Number }\end{array}$ & $\begin{array}{c}\text { Silymarin } \\
\text { concentration }\end{array}$ & $\begin{array}{c}\text { Incubation } \\
\text { time prior } \\
\text { to Silymarin } \\
\text { addition }\end{array}$ & $\begin{array}{c}\text { Incubation } \\
\text { time after } \\
\text { Silymarin } \\
\text { addition }\end{array}$ & $\begin{array}{c}\text { Total } \\
\text { incubation } \\
\text { time }\end{array}$ \\
\hline 1 & None & - & - & $48 \mathrm{hrs}$ \\
\hline 2 & $6.25 \mathrm{mg} / \mathrm{L}$ & $24 \mathrm{hrs}$ & $24 \mathrm{hrs}$ & $48 \mathrm{hrs}$ \\
\hline 3 & $25 \mathrm{mg} / \mathrm{L}$ & $24 \mathrm{hrs}$ & $24 \mathrm{hrs}$ & $48 \mathrm{hrs}$ \\
\hline 4 & None & & & $72 \mathrm{hrs}$ \\
\hline 5 & $6.25 \mathrm{mg} / \mathrm{L}$ & $24 \mathrm{hrs}$ & $48 \mathrm{hrs}$ & $72 \mathrm{hrs}$ \\
\hline 6 & $25 \mathrm{mg} / \mathrm{L}$ & $24 \mathrm{hrs}$ & $48 \mathrm{hrs}$ & $72 \mathrm{hrs}$ \\
\hline
\end{tabular}

Table 2. Demographic and clinical characteristics of severe preeclampsia and control groups

\begin{tabular}{|l|c|c|c|}
\hline & $\begin{array}{c}\text { Severe } \\
\text { preeclampsia } \\
\text { group (n=8) } \\
\text { mean } \pm \text { SD (range) }\end{array}$ & $\begin{array}{c}\text { Control group } \\
\text { (n=8) } \\
\text { mean } \pm \text { SD } \\
\text { (range) }\end{array}$ & p \\
\hline $\begin{array}{l}\text { Maternal age } \\
\text { (years) }\end{array}$ & $29.6 \pm 9.5(17-42)$ & $31.6 \pm 5.1(24-39)$ & $>0.05$ \\
\hline Parity & $1.9 \pm 2.7(0-8)$ & $0.4 \pm 0.5(0-1)$ & $>0.05$ \\
\hline $\begin{array}{l}\text { Gestational age } \\
\text { (weeks) }\end{array}$ & $\begin{array}{c}33.1 \pm 2.8 \\
(30-39)\end{array}$ & $\begin{array}{c}38.5 \pm 1.6 \\
(35-40)\end{array}$ & 0.002 \\
\hline $\begin{array}{l}\text { Systolic blood } \\
\text { pressure (mmHg) }\end{array}$ & $\begin{array}{c}155.0 \pm 9.3 \\
(140-170)\end{array}$ & $\begin{array}{c}111.3 \pm 8.3 \\
(100-120)\end{array}$ & 0.01 \\
\hline $\begin{array}{l}\text { Diastolic blood } \\
\text { pressure (mmHg) }\end{array}$ & $\begin{array}{c}105.0 \pm 9.3 \\
(90-120)\end{array}$ & $\begin{array}{c}68.8 \pm 6.4 \\
(60-80)\end{array}$ & 0.02 \\
\hline $\begin{array}{l}\text { Platelet count } \\
\text { (/mm } \text { ) }\end{array}$ & $\begin{array}{c}170250 \pm 72013.4 \\
(82,000-272,000)\end{array}$ & $\begin{array}{c}278250 \pm 127928.3 \\
(161000-550000)\end{array}$ & $>0.05$ \\
\hline $\begin{array}{l}\text { Newborn } \\
\text { weight (gr) }\end{array}$ & $\begin{array}{c}1870.0 \pm 600.9 \\
(1130-3010)\end{array}$ & $\begin{array}{c}3361.3 \pm 390.8 \\
(2840-3810)\end{array}$ & 0.03 \\
\hline
\end{tabular}


the remaining 8 patients were included in the control group. Demographic and clinical characteristics of the SP and control groups are presented in Table 2. In the SP group, 4 patients had systolic blood pressures $>160 \mathrm{mmHg}, 4$ had diastolic blood pressures $>110 \mathrm{mmHg}, 6$ had $>5 \mathrm{gr} / 24 \mathrm{hrs}$ proteinuria, and 2 had platelet counts less than $100,000 / \mathrm{mm}^{3}$. None of the women had oliguria, impaired renal or hepatic function tests, or laboratory findings suggesting haemolysis. Four foetuses in the SP group had foetal growth restriction.

Basal (no Silymarin) VEGF, sVEGF-R and IL-1 $\alpha$ levels in placental cultures of SP and control groups (wells 1 and 4) are presented in Tables 3 and 4 . When all cases $(n=16)$ were included in the analysis, there were no significant correlations between gestational age and placental VEGF, sVEGFR-1 and IL- $1 \alpha$ after 48 or 72 hours of incubation ( $p>0.05)$. On the other hand, basal VEGF levels after 72 hours of incubation had a significant correlation with newborn weight $(r=0.615, p=0.001)$. VEGF, sVEGFR-1 and IL-1 $\alpha$ levels after the administration of $6.25 \mathrm{mg} / \mathrm{L}$ and $25 \mathrm{mg} / \mathrm{L}$ Silymarin after 48 and 72 hours of incubation in the SP and control groups are presented in Table 5.

\section{Discussion}

Preeclampsia is a clinical condition that is specific to pregnancy, of which the underlying aetiopathological factors remain to be discovered. Recent investigations have focused on proinflammatory processes that cause disturbances in placental angiogenesis as an aetiological factor. In this study, we investigated VEGF, sVEGFR-1 and IL-1 $\alpha$ levels in placental cultures of pregnant women with severe preeclampsia compared to the control group with healthy pregnancies. In addition, the impact of low $(6.25 \mathrm{mg} / \mathrm{L})$ and high ( $25 \mathrm{mg} / \mathrm{L})$ concentrations of Silymarin, a drug with anti-angiogenic and anti-inflammatory properties, on these cytokine levels were assessed.

Vascular endothelial growth factor (VEGF) plays an important role in angiogenesis, induces nitrous oxide and prostacycline secretion from endothelial cells, and has a critical function in controlling the vascular tonus $(6,26,27)$. It also promotes the migration and adhesion of leukocytes to the inflammation site and increases vascular permeability, thereby acting as a cytokine with proinflammatory properties $(28,29)$. Previous studies have demonstrated that in cases with preeclampsia, inadequate invasion of spiral arterioles by trophoblasts commonly exists $(5,30)$. There are also studies that have reported lower local concentrations of angiogenic factors such as VEGF and PlGF in preeclamptic subjects $(1,8,9,31,32)$. On the other hand, some publications have claimed that defects in placental invasion of trophoblasts might result in increased VEGF levels (33).

In this study, we found that basal VEGF levels were lower in the SP group; however, it did not reach statistical significance. In addition, basal VEGF levels after 72 hours of incubation cor-

Table 3. Basal levels of VEGF, sVEGFR-1 and IL-1 $\alpha$ after 48 hours of incubation

\begin{tabular}{|l|c|c|c|}
\hline & $\begin{array}{c}\text { Severe } \\
\text { preeclampsia } \\
\text { group (n=8) } \\
\text { mean } \pm \text { SD (range) }\end{array}$ & $\begin{array}{c}\text { Control group } \\
(\mathbf{n = 8 )} \\
\text { mean } \pm \text { SD } \\
\text { (range) }\end{array}$ & p \\
\hline VEGF $(\mathrm{pg} / \mathrm{mL})$ & $\begin{array}{c}12.75 \pm 7.59 \\
(7.230-29.401)\end{array}$ & $\begin{array}{c}23.64 \pm 32.06 \\
(5.429-95.910)\end{array}$ & $>0.05$ \\
\hline sVEGFR-1 $(\mathrm{pg} / \mathrm{mL})$ & $\begin{array}{c}8.29 \pm 4.93 \\
(1.096-14.933)\end{array}$ & $\begin{array}{c}5.43 \pm 3.34 \\
(1.332-11.257)\end{array}$ & $>0.05$ \\
\hline IL-1 $\alpha(\mathrm{pg} / \mathrm{mL})$ & $1.05 \pm 0.46$ & $1.07 \pm 0.16$ & $>0.05$ \\
& $(0.643-2.051)$ & $(0.792-1.274)$ & \\
\hline
\end{tabular}

VEGF: Vascular endothelial growth factor; sVEGFR-1: Soluble VEGF receptor-1; IL1 $\alpha$ : Interleukin1 alpha

Table 4. Basal levels of VEGF, sVEGFR-1 and IL-1 $\alpha$ after 72 hours of incubation (Well 4)

\begin{tabular}{|l|c|c|c|}
\hline & $\begin{array}{c}\text { Severe } \\
\text { preeclampsia } \\
\text { group (n=8) } \\
\text { mean } \pm \text { SD (range) }\end{array}$ & $\begin{array}{c}\text { Control group } \\
(\mathbf{n = 8 )} \\
\text { mean } \pm \text { SD } \\
\text { (range) }\end{array}$ & p \\
\hline VEGF $(\mathrm{pg} / \mathrm{mL})$ & $\begin{array}{c}12.19 \pm 3.37 \\
(8.269-19.327)\end{array}$ & $\begin{array}{c}32.95 \pm 24.85 \\
(8.542-73.141)\end{array}$ & $>0.05$ \\
\hline sVEGFR-1 (pg/mL) & $\begin{array}{c}8.12 \pm 2.81 \\
(4.652-12.169)\end{array}$ & $\begin{array}{c}6.08 \pm 3.51 \\
(1.474-13.258)\end{array}$ & $>0.05$ \\
\hline IL-1 $\alpha(\mathrm{pg} / \mathrm{mL})$ & $1.03 \pm 0.53$ & $1.05 \pm 0.36$ & $>0.05$ \\
& $(0.739-2.315)$ & $(0.668-1.892)$ & \\
\hline
\end{tabular}

VEGF: Vascular endothelial growth factor; sVEGFR-1: Soluble VEGF receptor-1; IL1 $\alpha$ : Interleukin1

Table 5. VEGF, sVEGFR-1 and IL-1 $\alpha$ levels after administration of Silymarin

\begin{tabular}{|c|c|c|c|c|c|c|c|c|c|}
\hline & & $\begin{array}{c}\text { Basal 48h } \\
(\mathrm{pg} / \mathrm{mL})\end{array}$ & $\begin{array}{c}\text { Silymarin } \\
6.25 \mathrm{mg} / \mathrm{L} \\
48 \mathrm{~h}(\mathrm{pg} / \mathrm{mL})\end{array}$ & $\begin{array}{c}\text { Silymarin } \\
25 \mathrm{mg} / \mathrm{L} \\
48 \mathrm{~h}(\mathrm{pg} / \mathrm{mL})\end{array}$ & $\mathbf{p}$ & $\begin{array}{c}\text { Basal } \\
72 \mathrm{~h}(\mathrm{pg} / \mathrm{mL})\end{array}$ & $\begin{array}{c}\text { Silymarin } \\
6.25 \mathrm{mg} / \mathrm{L} \\
72 \mathrm{~h}(\mathrm{pg} / \mathrm{mL})\end{array}$ & $\begin{array}{c}\text { Silymarin } \\
25 \mathrm{mg} / \mathrm{L} \\
72 \mathrm{~h}(\mathrm{pg} / \mathrm{mL})\end{array}$ & $\mathbf{p}$ \\
\hline \multirow{3}{*}{$\begin{array}{l}\text { Control } \\
\text { Group }\end{array}$} & VEGF & $23.6 \pm 32$ & $28.8 \pm 28.5$ & $27.4 \pm 28.2$ & $>0.05$ & $32.9 \pm 24.9$ & $38.5 \pm 48.8$ & $48.9 \pm 54.2$ & $>0.05$ \\
\hline & VEGFR-1 & $5.4 \pm 3.3$ & $5.0 \pm 2.5$ & $5.8 \pm 2.4$ & $>0.05$ & $6.0 \pm 3.5$ & $4.8 \pm 1.5$ & $4.2 \pm 0.6$ & $>0.05$ \\
\hline & IL-1 $\alpha$ & $1.0 \pm 0.16$ & $1.0 \pm 0.16$ & $1.0 \pm 0.18$ & $>0.05$ & $1.0 \pm 0.36$ & $1.3 \pm 0.6$ & $1.1 \pm 0.47$ & $>0.05$ \\
\hline \multirow{3}{*}{$\begin{array}{l}\text { Severe } \\
\text { Preeclampsia }\end{array}$} & VEGF & $12.7 \pm 7.6$ & $17.6 \pm 10.7$ & $13.2 \pm 5.5$ & $>0.05$ & $12.2 \pm 3.3$ & $14.3 \pm 5.9$ & $18.5 \pm 11.4$ & $>0.05$ \\
\hline & VEGFR-1 & $8.2 \pm 4.9$ & $6.4 \pm 3.7$ & $5.5 \pm 4.3$ & $>0.05$ & $8.1 \pm 2.8$ & $6.0 \pm 3.5$ & $4.8 \pm 3.4$ & $>0.05$ \\
\hline & IL-1 $\alpha$ & $1.0 \pm 0.46$ & $1.4 \pm 0.86$ & $1.5 \pm 1.6$ & $>0.05$ & $1.0 \pm 0.5$ & $1.8 \pm 1.3$ & $1.7 \pm 1.6$ & $>0.05$ \\
\hline
\end{tabular}


related significantly with newborn weight. Not surprisingly, our findings of decreased VEGF levels in FGR support the claim that inadequate placentation might be an important aetiological factor in these cases (34).

Previous studies have reported increased VEGFR-1 levels in cases with preeclampsia (1, 13, 35-38). It has also been suggested that high levels of sVEGFR-1 inhibits angiogenesis by antagonising the effects of VEGF and PIGF $(39,40)$. It has also been shown that sVEGFR-1 levels positively correlate with the severity of preeclampsia $(1,9)$. In this study, we could not demonstrate significantly different VEGFR-1 levels in placental cultures of women with SP compared to controls ( $p>0.05$ ).

IL- $1 \alpha$ and IL-1 $\beta$ are secreted from monocytes and tissue macrophages, therefore playing a role in acute and chronic inflammation $(15,41)$. It has also been previously reported that IL-1 has a role in maternal inflammatory response and endothelial dysfunction in preeclamptic women (42). In several studies, it has been shown that IL- $1 \alpha$ secretion from placental villous tissue is increased in accordance with tissue hypoxia (43-45). From this point of view, in this study, we compared IL- $1 \alpha$ levels in placental samples between severely preeclamptic women and controls. However, IL-1 $\alpha$ levels were similar between the two groups after 48 and 72 hours of incubation.

Silymarin is a flavonoid with anti-proliferative, anti-inflammatory, anti-oxidant, pro-apoptotic, anti-angiogenic and anti-fibrotic properties that is derived from the plant Silybum marianum (46). It has been previously investigated as a drug against cancer, diabetes, chemotherapeutic resistance, and biliary disturbances in pregnant women. In this study, we investigated the effects of low $(6.25 \mathrm{mg} / \mathrm{L})$ and high $(25 \mathrm{mg} / \mathrm{L})$ concentrations of Silymarin on placental VEGF, sVEGFR-1 and IL-1 $\alpha$ levels in severely preeclamptic and control (healthy pregnant) subjects. Compared to basal VEGF levels, we observed a Silymarin dose-dependent rise in VEGF levels in the SP and control groups after 72 hours of incubation $(p=0.01)$.

After 42 and 72 hours of incubation, sVEGFR-1 levels in Silymarin added SP and control placental cultures were lower than the samples without the addition of Silymarin; however, this difference did not reach significance. Interestingly, we also observed that this decline was positively correlated with Silymarin dose and incubation duration. These results suggest that Silymarin may have favourable effects in SP cases. IL-1 $\alpha$ levels after incubation periods in Silymarin added SP and control groups were similar to levels in the samples without the addition of Silymarin. The mean gestational age was higher in the control group when compared with the SP group. As basal VEGF, sVEGFR-1 and IL-1 $\alpha$ levels in the SP and control groups were similar after 48 and 72 hours of incubation, an analysis including all study subjects $(n=16)$ was conducted to determine the associations between gestational age and VEGF, sVEGFR-1 and IL-1 $\alpha$ levels after 48 and 72 hours of incubation. However, no significant correlations were noted between these groups. Thus, we assumed that the difference between gestational ages of study groups did not have any effect on our findings.
In currently ongoing studies, the role of secretion and the effects of placental cytokines in preeclampsia pathogenesis are being investigated. Considering the role of vasospasm, inflammation, angiogenesis, endothelial cell activation, and oxidative stress in preeclampsia, the potential benefits of Silymarin should be evaluated in future trials.

Ethics Committee Approval: Ethics committee approval was received for this study from Başkent University Scientific and Ethical Committee (KA 08/57).

Informed Consent: Written informed consent was obtained from patients who participated in this study.

Peer-review: Externally peer-reviewed.

Author contributions: Concept - M.D.K., F.Y.; Design - M.D.K.; Supervision - F.Y., E.K. Resource - M.D.K, S.K., E.B.; Materials F.S.,, S.K.; Data Collection\&/or Processing - M.D.K., E.B.,; Analysis\&/or Interpretation - M.D.K., F.Y., E.K.; Literature Search E.B., M.K.T., S.K.; Writing - M.D.K., E.B., M.K.T.; Critical Reviews F.Y., E.K.

Conflict of Interest: No conflict of interest was declared by the authors.

Financial Disclosure: The study was financially supported by Başkent University Faculty of Medicine.

\section{References}

1. Levine RJ, Maynard SE, Qian C, Lim KH, England LJ, Yu KF, et al. Circulating angiogenic factors and the risk of preeclampsia. N Engl J Med 2004; 350: 672-83. [CrossRef]

2. Davey DA, MacGillivray I. The classification and definition of the hypertensive disorders of pregnancy. Am J Obstet Gynecol 198; 158: 892-8.

3. Lam C, Lim KH, Karumanchi SA. Circulating angiogenic factors in the pathogenesis and prediction of preeclampsia. Hypertension 2005; 46:1077-85. [CrossRef]

4. Lyall F. Priming and remodelling of human placental bed spiral arteries during pregnancy--a review. Placenta. 2005; 26 Suppl A: S31-6

5. Wheeler T, Evans PW, Anthony FW, Godfrey KM, Howe DT, Osmond C. Relationship between maternal serum vascular endothelial growth factor concentration in early pregnancy and fetal and placental growth. Hum Reprod 1999; 14:1619-23. [CrossRef]

6. Brockelsby J, Hayman R, Ahmed A, Warren A, Johnson I, Baker P. VEGF via VEGF receptor-1 (Flt-1) mimics preeclamptic plasma in inhibiting uterine blood vessel relaxation in pregnancy: implications in the pathogenesis of preeclampsia. Lab Invest 1999; 79: 1101-11.

7. Ahmad S, Ahmed A. Elevated placental soluble vascular endothelial growth factor receptor-1 inhibits angiogenesis in preeclampsia. Circ Res 2004; 95: 884-91. [CrossRef]

8. Koga K, Osuga Y, Yoshino O, Hirota Y, Ruimeng X, Hirata T, et al. Elevated serum soluble vascular endothelial growth factor receptor 1 (sVEGFR-1) levels in women with preeclampsia. J Clin Endocrinol Metab 2003; 88: 2348-51. PubMed PMID: 12727995. [CrossRef]

9. Maynard SE, Min JY, Merchan J, Lim KH, Li J, Mondal S, et al. Excess placental soluble fms-like tyrosine kinase 1 (sFlt1) may contribute 
to endothelial dysfunction, hypertension, and proteinuria in preeclampsia. J Clin InvestJ Clin Invest 2003; 111: 649-58. [CrossRef]

10. Taylor RN, Grimwood J, Taylor RS, McMaster MT, Fisher SJ, North RA. Longitudinal serum concentrations of placental growth factor: evidence for abnormal placental angiogenesis in pathologic pregnancies. Am J Obstet Gynecol 2003; 188: 177-82. [CrossRef]

11. Tidwell SC, Ho HN, Chiu WH, Torry RJ, Torry DS. Low maternal serum levels of placenta growth factor as an antecedent of clinical preeclampsia. Am J Obstet Gynecol 2001; 184: 1267-72. [CrossRef]

12. Polliotti BM, Fry AG, Saller DN, Mooney RA, Cox C, Miller RK. Second-trimester maternal serum placental growth factor and vascular endothelial growth factor for predicting severe, early-onset preeclampsia. Obstet Gynecol 2003; 101: 1266-74. [CrossRef]

13. Chaiworapongsa T, Romero R, Kim YM, Kim GJ, Kim MR, Espinoza $\mathrm{J}$, et al. Plasma soluble vascular endothelial growth factor receptor-1 concentration is elevated prior to the clinical diagnosis of preeclampsia. J Matern Fetal Neonatal Med 2005; 17: 3-18. [CrossRef]

14. Rinehart BK, Terrone DA, Lagoo-Deenadayalan S, Barber WH, Hale EA, Martin JN Jr, Bennett WA. Expression of the placental cytokines tumor necrosis factor alpha, interleukin lbeta, and interleukin 10 is increased in preeclampsia. Am J Obstet Gynecol 1999; 181: 915-20. [CrossRef]

15. Dinarello CA. Interleukin-1beta and the autoinflammatory diseases. N Engl J Med 2009; 360: 2467-70. [CrossRef]

16. Wang Y, Gu Y, Philibert L, Lucas MJ. Neutrophil activation induced by placental factors in normal and pre-eclamptic pregnancies in vitro. Placenta 2001; 22: 560-5. [CrossRef]

17. Kren V, Walterova D. Silybin and silymarin--new effects and applications. Biomed Pap Med Fac Univ Palacky Olomouc Czech Repub 2005; 149: 29-41. [CrossRef]

18. Hackett ES, Twedt DC, Gustafson DL. Milk thistle and its derivative compounds: a review of opportunities for treatment of liver disease. J Vet Intern Med 2013; 27: 10-6. [CrossRef]

19. Souza CO, Peracoli MT, Weel IC, Bannwart CF, Romao M, NakairaTakahagi E, et al. Hepatoprotective and anti-inflammatory effects of silibinin on experimental preeclampsia induced by L-NAME in rats. Life Sci 2012; 91: 159-65. [CrossRef]

20. Das SK, Mukherjee S. Biochemical and immunological basis of silymarin effect, a milk thistle (Silybum marianum) against ethanol-induced oxidative damage. Toxicol Mech Methods 2012; 22: 409-13. [CrossRef]

21. Tsai MJ, Liao JF, Lin DY, Huang MC, Liou DY, Yang HC, et al. Silymarin protects spinal cord and cortical cells against oxidative stress and lipopolysaccharide stimulation. Neurochem Int 2010; 57: 867-75. [CrossRef]

22. Fu H, Lin M, Katsumura Y, Yokoya A, Hata K, Muroya Y, et al. Protective effects of silybin and analogues against X-ray radiationinduced damage. Acta Biochim Biophys Sin (Shanghai) 2010; 42: 489-95. [CrossRef]

23. Trappoliere M, Caligiuri A, Schmid M, Bertolani C, Failli P, Vizzutti F, et al. Silybin, a component of sylimarin, exerts anti-inflammatory and anti-fibrogenic effects on human hepatic stellate cells. J Hepatol 2009; 50: 1102-11. [CrossRef]

24. Raina K, Rajamanickam S, Singh RP, Deep G, Chittezhath M, Agarwal R. Stage-specific inhibitory effects and associated mechanisms of silibinin on tumor progression and metastasis in transgenic adenocarcinoma of the mouse prostate model. Cancer Res 2008; 68: 6822-30. [CrossRef]

25. Wang YK, Hong YJ, Huang ZQ. Protective effects of silybin on human umbilical vein endothelial cell injury induced by $\mathrm{H} 2 \mathrm{O} 2$ in vitro. Vascul Pharmacol 2005; 43: 198-206. [CrossRef]
26. Morbidelli L, Chang CH, Douglas JG, Granger HJ, Ledda F, Ziche M. Nitric oxide mediates mitogenic effect of VEGF on coronary venular endothelium. Am J Physiol 1996; 270: H411-5.

27. Ku DD, Zaleski JK, Liu S, Brock TA. Vascular endothelial growth factor induces EDRF-dependent relaxation in coronary arteries. Am J Physiol 1993; 265: H586-92.

28. Wu Y, Zhu Z. Vascular endothelial growth factor receptor 1, a therapeutic target in cancer, inflammation and other disorders. Curr Med Chem 2009; 16: 2890-8. [CrossRef]

29. Gandley RE, Tyurin VA, Huang W, Arroyo A, Daftary A, Harger G, et al. S-nitrosoalbumin-mediated relaxation is enhanced by ascorbate and copper: effects in pregnancy and preeclampsia plasma. Hypertension 2005; 45: 21-7. [CrossRef]

30. Hunt JS, Chen HL, Miller L. Tumor necrosis factors: pivotal components of pregnancy? Biol Reprod 1996; 54: 554-62. [CrossRef]

31. Sharkey AM, Charnock-Jones DS, Boocock CA, Brown KD, Smith SK. Expression of mRNA for vascular endothelial growth factor in human placenta. J Reprod Fertil 1993; 99: 609-15. [CrossRef]

32. Tsatsaris V, Goffin F, Munaut C, Brichant JF, Pignon MR, Noel A, et al. Overexpression of the soluble vascular endothelial growth factor receptor in preeclamptic patients: pathophysiological consequences. J Clin Endocrinol Metab 2003; 88: 5555-63. [CrossRef]

33. Ahmed A, Dunk C, Ahmad S, Khaliq A. Regulation of placental vascular endothelial growth factor (VEGF) and placenta growth factor (PIGF) and soluble Flt-1 by oxygen--a review. Placenta 2000; 21 Suppl A: S16-24.

34. Regnault TR, de Vrijer B, Galan HL, Davidsen ML, Trembler KA, Battaglia $\mathrm{FC}$, et al. The relationship between transplacental $\mathrm{O} 2$ diffusion and placental expression of PIGF, VEGF and their receptors in a placental insufficiency model of fetal growth restriction. J Physiol 2003; 550: 641-56. [CrossRef]

35. Reddy A, Suri S, Sargent IL, Redman CW, Muttukrishna S. Maternal circulating levels of activin A, inhibin A, sFlt-1 and endoglin at parturition in normal pregnancy and pre-eclampsia. PLoS One 2009; 4: e4453. [CrossRef]

36. Chaiworapongsa T, Romero R, Espinoza J, Bujold E, Mee Kim Y, Goncalves LF, et al. Evidence supporting a role for blockade of the vascular endothelial growth factor system in the pathophysiology of preeclampsia. Young Investigator Award. Am J Obstet Gynecol 2004; 190: 1541-7. [CrossRef]

37. McKeeman GC, Ardill JE, Caldwell CM, Hunter AJ, McClure N. Soluble vascular endothelial growth factor receptor-1 (sFlt-1) is increased throughout gestation in patients who have preeclampsia develop. Am J Obstet Gynecol 2004; 191: 1240-6. [CrossRef]

38. Staff AC, Braekke K, Harsem NK, Lyberg T, Holthe MR. Circulating concentrations of sFlt1 (soluble fms-like tyrosine kinase 1) in fetal and maternal serum during pre-eclampsia. Eur J Obstet Gynecol Reprod Biol 2005; 122: 33-9. [CrossRef]

39. Ahmed A, Li XF, Dunk C, Whittle MJ, Rushton DI, Rollason T. Colocalisation of vascular endothelial growth factor and its Flt-1 receptor in human placenta. Growth Factors 1995; 12: 23543. [CrossRef]

40. Shibuya M. Structure and function of VEGF/VEGF-receptor system involved in angiogenesis. Cell Struct Funct 2001; 26: 25-35. [CrossRef]

41. Bird S, Zou J, Wang T, Munday B, Cunningham C, Secombes CJ. Evolution of interleukin-1beta. Cytokine Growth Factor Rev 2002; 13: 483-502. [CrossRef]

42. Rusterholz C, Gupta AK, Huppertz B, Holzgreve W, Hahn S. Soluble factors released by placental villous tissue: Interleukin-1 is a poten- 
tial mediator of endothelial dysfunction. Am J Obstet Gynecol 2005; 192: 618-24. [CrossRef]

43. Benyo DF, Miles TM, Conrad KP. Hypoxia stimulates cytokine production by villous explants from the human placenta. J Clin Endocrinol Metab 1997; 82: 1582-8. [CrossRef]

44. Kocyigit Y, Atamer Y, Atamer A, Tuzcu A, Akkus Z. Changes in serum levels of leptin, cytokines and lipoprotein in pre-eclamptic and normotensive pregnant women. Gynecol Endocrinol 2004; 19: 267-73. [CrossRef]
45. Luppi P, Deloia JA. Monocytes of preeclamptic women spontaneously synthesize pro-inflammatory cytokines. Clin Immunol 2006; 118: 268-75. [CrossRef]

46. Singh RP, Tyagi AK, Zhao J, Agarwal R. Silymarin inhibits growth and causes regression of established skin tumors in SENCAR mice via modulation of mitogen-activated protein kinases and induction of apoptosis. Carcinogenesis 2002; 23: 499-510. [CrossRef] 